\title{
Analysis of Leading Sectors and the Role of MSMEs in the Kedungsepur Development Area in Supporting Central Java Economy
}

\author{
Ida Puspitowati ${ }^{1 *}$, Tri Widayati ${ }^{2}$ \\ ${ }^{1}$ Faculty of Economics and Business, Universitas Tarumanagara, Jakarta, Indonesia \\ ${ }^{2}$ Faculty of Economics and Business, University of 17 Agustus 1945 (Untag), Semarang, Indonesia \\ *Corresponding author. Email: idap@fe.untar.ac.id
}

\begin{abstract}
Kedungsepur economic-growth as a whole continues to increase. The average economic-growth of Kedungsepur from 2011 to 2018 was 5.58\%, higher than that of Central Java. The difference in economic growth of each region in Kedungsepur indicates a disparity in income. However, as the area which is expected to be the driver for area economy including Central Java, and also as the role of Kedungsepur MSMEs that still have the potentials to be expanded, it is crucial to know what sectors that can be expanded for this reason. This paper aimed to identify some matters related to the regency / city economic growth, analyze the sectors that have the potentials to be developed in order to encourage economic growth, categorize regions and regency / city sectors in Kedungsepur based on growth-rates and per-capita-income / contribution. The analysis method used is the Klassen typology analysis. The results of this study indicate that: The manufacturing sector and the provision of accommodation are the leading sectors with the potentials to encourage economic growth in each regency / city in Kedungsepur. The development of leading sectors that have become the basic sectors in each region is meant to accelerate the rate of economic-growth, and furthermore to be the crucial part to push the economy in Central Java, especially in the manufacturing sector with agro-industry, thereby creating intersectoral links.
\end{abstract}

Keywords: economic growth, regional development

\section{INTRODUCTION}

A continuous process towards the change to improve the welfare of society is regarded as development. One indicator of a successful implementation of development that can be used as a macro benchmark is economic growth, reflected in changes in the Gross Regional Domestic Product (GRDP). The higher the economic growth of a region, the better the economic activity based on GRDP growth-rate at constant prices [26]. Economic growth is strongly influenced by the productivity of sectors in using their production factors [24].

Regional economic development is a process in which local governments manage the existing resources to form a partnership pattern between local governments and the private sector to create new jobs and stimulate the development of economic activity (economic growth) in the region [1]. The sector which is currently capable of being the driving sector, both on a national and regional scale, is the industrial sector.

The economic growth of Central Java in 2019 was $5.41 \%$, higher than that of $2018(5.31 \%)$. During the last 5 (five) years, 5 (five) major sectors, namely the manufacturing sector, wholesale and retail trade, car and motorcycle repair, agriculture, forestry and fisheries, construction and the education services sector contributed toward the Central Java's GRDP [10].

During the pandemic, the manufacturing-industry business is one of many sectors negatively affected by the COVID19 Pandemic. Social distancing has not only reduced the demand for industrial products, but also limits the production activities due to the restrictions on operational working hours. In Central Java, the processing industry other than oil and gas processing, was generally affected by the weakening domestic and global demand. The rate of national household consumption only grew by $2.84 \%$ (yoy) in the first quarter of 2020 , much lower than that in the previous quarter $(4.97 \%$, yoy) [19].

To improve economic growth and achieve equal regional development, the Central Java provincial government has established an inter-regional cooperation area that can be utilized for equal development within the area. Based on the Regional Regulation Number 16 Year 2019 concerning the Regional Spatial Development Plan for the Province of Central Java, there are 8 (eight) Development Areas in Central Java, including those with the development links between physical, social, economic, and / or cultural aspects. Strategic Developmental Areas also cover the growth areas and potential borders with different growth accelerations so that they can be developed effectively [18]. 
Kedungsepur Development Area is a regional area with economic, social and / or cultural development links that covers Kendal Regency, Demak Regency, Semarang Regency, Semarang City, Salatiga City, and Grobogan Regency.

The manufacturing and agricultural sectors are the sectors with the potential to boost economic growth in each district / city in Kedungsepur [17]. The research conducted by [12] also found an inequality among those sectors in the Kedungsepur area, which in turn becomes an opportunity to implement economic development strategies in the Kedungsepur area based on a typology of economic growth and sector inequality.
The research conducted by [17] in the Kedungsepur area found that investment has no significant effect on inequality in the Kedungsepur area, HDI has a significant effect on inequality in the Kedungsepur area, LFPR has no significant effect on inequality in the Kedungsepur area, and population has a significant effect on inequality in the Kedungsepur area, and there has been convergence in the Kedungsepur area.

Based on data from the Central Java Central Statistics Bureau [9], the average economic-growth of the City / Regency in the Kedungsepur Region in 2011-2018 compared to Central Java can be seen in the following table.

Table 1 Economic Growth in Central Java Province and Kedungsepur Region in 2011-2018 (\%)

\begin{tabular}{|c|l|c|c|c|c|c|c|c|c|c|}
\hline Num & Province / Regency / City & 2011 & 2012 & 2013 & 2014 & 2015 & 2016 & 2017 & 2018 & Average \\
\hline 1 & Province of Central Java & 5.30 & 5.34 & 5.11 & 5.27 & 5.47 & 5.25 & 5.26 & 5.32 & 5.29 \\
\hline 2 & Salatiga City & 6.58 & 5.53 & 6.30 & 5.57 & 5.17 & 5.27 & 5.65 & 5.51 & 5.70 \\
\hline 3 & Kendal Regency & 6.57 & 5.21 & 6.22 & 5.14 & 5.21 & 5.56 & 5.84 & 5.50 & 5.65 \\
\hline 4 & Demak Regency & 5.39 & 4.46 & 5.27 & 4.29 & 5.93 & 5.09 & 5.82 & 5.37 & 5.20 \\
\hline 5 & Semarang Regency & 6.27 & 6.03 & 5.97 & 5.85 & 5.52 & 5.30 & 5.65 & 5.79 & 5.80 \\
\hline 6 & Grobogan Regency & 3.19 & 5.08 & 4.57 & 4.07 & 5.96 & 4.51 & 5.85 & 5.91 & 4.89 \\
\hline 7 & Semarang City & 6.58 & 5.97 & 6.25 & 6.31 & 5.82 & 5.89 & 6.55 & 6.52 & 6.24 \\
\hline
\end{tabular}

Source: Central Java BPS, various years of publication (processed);

\section{Note: 2017: Temporary Figures, 2018: Very Temporary Figures}

In Table 1, it can be seen that the average economic-growth of Cities and Regencies in Kedungsepur Development Area is higher than that of Central Java Province, except for Demak Regency, until 2018.

In Table 1, it can also be seen that regarding the rate of economic growth, Kedungsepur region has higher average economic-growth compared to that of Central Java in the 2011-2018 period.

The role of Kedungsepur area development is expected to be the driver of the area economy with area characteristic that grows faster than other areas that haven't been able to do so optimally. This phenomenon can be seen by the economic position, especially the growth of Gross Domestic Regional Product. Based on the truth and problems, it is necessary that analysis on leading sector which can be the driver of economic growth in Kedungsepur Development Area to support the economic growth in Central Java, to be performed.

The role of strategic Micro, Small, and Medium Enterprises (MSMEs) on the development of either National or Central Java economy makes the government and other parties put their attention more towards the existence and development of those businesses. It is proven that MSMEs businesses are able to absorb the most amount of labor and resilient towards the crisis that happened in Indonesia both in 1998 and 2008. It is one of the indications that MSMEs have gained huge amount of attention from both government and private sectors. Based on data obtained from MSMEs in Central Java, MSMEs in Central Java contributed nearly $50 \%$ in poverty alleviation efforts [13]. MSMEs play a major role by starting a business with the capital they have, which provides continuous income. During the current Pandemic period, there was a decrease in the income of both Micro and Small Enterprises (86.2\%) and Medium and Big Enterprises $(83.1 \%$ ) [10], whereas in 2020 there was an increase in the role of MSMEs in Central Java's economic growth.

The Kedungsepur area which was part of Central Java Residency, namely the Semarang Residency, based on BPS data [10] which includes Kendal Regency, Semarang City, Demak Regency, Jepara Regency, it was found that averagely $52.93 \%$ of businesses were still operating during the Pandemic. This situation shows that Micro and Small Enterprises and Medium and Big Enterprises in several Kedungsepur areas still contribute to the economic growth of Central Java.

There are as many as 4,170,852 MSMEs in Central Java in 2019, and the distribution in the Kedungsepur Development Area is as such: 17,602 MSMEs in Semarang City, 20,000 MSMEs in Kendal Regency, 15,000 MSMEs in Demak 
Regency, 32,055 MSMEs in Grobogan Regency, 11,428 MSMEs in Semarang Regency, and 10,000 MSMEs in Salatiga City. MSMEs in the Kedungsepur Development Area form $2.5 \%$ of the total MSMEs in Central Java. This shows that SMEs and SMBs in several Kedungsepur areas can still contribute to the economic growth of Central Java. Based on the above conditions, several problems were found regarding:

1. Leading Sectors that support economic growth in Kedungsepur.

2. The state of economic growth of each region in Kedungsepur.

3. Micro and Small Enterprises and Medium and Big Enterprises policies to encourage economic growth in Central Java.

\section{METHODOLOGY}

\section{Economic-Growth Theory}

Economic growth is defined as the process of long-term increase in per-capita-output. The neo-classical growth model was pioneered by Robert M. Solow. This model is a development of the Harrod-Domar formulation by adding labor factors, capital factors, and technology variable [26].

\section{Economic-Base Theory}

The economic base theory states that the main determinant of a region's economic-growth is related to the demand of goods and services from outside the region, such as the use of labor resources and raw materials that will generate regional wealth and create jobs. This theory can also be used to identify and determine whether a sector / industry is a base or non-base sector / industry [2] [15] [16].

\section{Previous Studies}

[14] conducted a research on leading sectors in Kubu Raya Regency and found that the sectors with competitive advantage and specialization (allocation advantage) are the manufacturing sector and the electricity, gas, and clean water sector. [23] examined the leading sectors in Central Java, and concluded that the leading industries in Central Java Province include the beverage industry, the tobacco industry, the textile industry, the apparel industry, the lumbering industry, the printing industry, the furniture industry, and other manufacturing industries. The research conducted by [20] found that the leading sectors in Sleman Regency are the construction sector, the transportation and warehousing sector, the real-estate sector, and the corporate services sector.

\subsection{Leading Sector}

[11] defined leading economic sector as a sector that can support and accelerate regional economic development and growth based on the criteria of the sector's ability to contribute to regional GDP revenue, the level of ability to absorb labor, the potential to produce export commodities, and the strong links with other sectors.

The type of data used in this study is secondary data, which is time-series data from Gross Regional Domestic Product (GRDP) according to business sectors, at constant prices during the 2015-2018 period. Data was obtained from the Central Statistics Bureau (BPS) of Central Java Province and Districts / Cities in Kedungsepur Region, as well as other related institutions.

\subsection{Analysis Instrument Used}

1. Base Sector.

To determine the base sector, the Location Quotient (LQ) analysis is used [21].

$\mathrm{LQ}=\mathrm{Si} / \mathrm{S} \mathrm{Ni} / \mathrm{N}$

Whereas: $\mathrm{Si}$ is the added-value of sector $\mathrm{i}$ in the regency / city; $\mathrm{S}$ is the GRDP in the regency / city; $\mathrm{Ni}$ is the addedvalue of sector $i$ in KEDUNGSEPUR; and $N$ is the GRDP in KEDUNGSEPUR. If the value of LQ is greater than 1, then the sector is a base sector, and if the value of LQ is less than 1 , then the sector is a non-base sector.

\section{Shift-Share analysis.}

According to [21], the shift-share analysis compares the differences in the growth rate of various sectors in smaller regions with the national growth-rate. [1] stated that this analysis provides data on economic performance in 3 related areas, namely: 1. Regional economic-growth is measured by analyzing sectoral aggregate changes compared to changes in the same sectors of the economy used as a reference. 2. Proportional Shift measures the relative change, incline or decline in an area in comparison to the larger economy that is used as a reference. This measurement allows us to find out whether the regional economy is concentrated on industries that are growing faster than the economy used as a reference. 3. Differential Shift helps determine how the competitiveness of regional (local) industries is compared to the economy being used as a reference. Therefore, if the differential shift of an industry is positive, then such industry is more competitive than the same industry in the economy that is used as a reference. The method of calculating Shift-Share is as follows:

$\mathrm{SS}=\mathrm{G}-\mathrm{R}$

$\mathrm{G}=$ Ert - Ero

$\mathrm{R}=$ Ero*(Ent $/$ Eno)

$\mathrm{S}=$ Ert $-($ Ent $/$ Eno $) *$ Ero

Whereas:

$\mathrm{SS}=$ Shift-Share

Ert $=$ District economic growth-rate in year $\mathrm{t}$

Ero $=$ District economic growth-rate in year 0

Ent $=$ Central Java Province economic growth-rate in year $\mathrm{t}$ Eno $=$ Central Java Province economic growth-rate in year 0

$\mathrm{G}=$ Growth

$\mathrm{R}=$ District economic growth-rate based on national growth-rate 


\section{Klassen-Typology Analysis}

Klassen Typology basically divides regions based on two main indicators, namely regional economic-growth and regional per-capita-income. In this study, the regional economic-growth is measured by GRDP growth, while the regional per-capita-income is measured by GRDP-percapita. The observed regions can be divided into four classifications, such as high-growth and high-income regions, high-income but low-growth regions, high-growth but low-income regions, and relatively struggling regions (low-growth and low-income) [25]. The analytical tool used to categorize areas in order to identify the level of development progress between regions is the Klassen Typology. This model was introduced by Leo Klassen in 1965. Klassen Typology compares per-capita-income with economic growth. Through the results of this comparison, 4 (four) categories of region classification can be obtained, such as:

a. Developed regions (Quadrant I), including the regions with above-average growth-rate and per-capita-income;

b. Developing regions (Quadrant II), including the regions with above-average growth-rate but below-average percapita-income; c. Developed but depressed regions (Quadrant III), including the regions with below-average growth-rate but above-average per-capita-income; and

d. Relatively undeveloped regions (Quadrant IV), including the regions with below-average growth-rate and per-capita-income

\section{RESULTS AND DISCUSSIONS}

\subsection{Leading Sector Analysis}

[11] defined leading economic sector as a sector that can support and accelerate regional economic development and growth based on the criteria of the sector's ability to contribute to regional GDP revenue, the level of ability to absorb labor, the potential to produce export commodities, and the strong links with other sectors. The leading sector analysis is obtained from the typology of the economic sector based on the combination of the average regional LQ value and the micro-regional share-growth components as depicted in a matrix.

Table 2 LQ and Shift Share Analysis of Kedungsepur Development Area

\begin{tabular}{|c|c|c|c|c|c|c|c|c|c|c|c|c|c|}
\hline \multirow{2}{*}{ \# } & \multirow{2}{*}{ Sectors } & \multicolumn{2}{|c|}{$\begin{array}{l}\text { Grobogan } \\
\text { Regency }\end{array}$} & \multicolumn{2}{|c|}{ Demak Regency } & \multicolumn{2}{|c|}{$\begin{array}{l}\text { Semarang } \\
\text { Regency }\end{array}$} & \multicolumn{2}{|c|}{$\begin{array}{c}\text { Kendal } \\
\text { Regency* }\end{array}$} & \multicolumn{2}{|c|}{ Salatiga City } & \multicolumn{2}{|c|}{ Semarang City } \\
\hline & & LQ & $\begin{array}{l}\text { Shift } \\
\text { share }\end{array}$ & LQ & $\begin{array}{l}\text { Shift } \\
\text { share }\end{array}$ & LQ & $\begin{array}{l}\text { Shift } \\
\text { share }\end{array}$ & LQ & $\begin{array}{l}\text { Shift } \\
\text { share }\end{array}$ & LQ & $\begin{array}{l}\text { Shift } \\
\text { share }\end{array}$ & LQ & $\begin{array}{l}\text { Shift } \\
\text { share }\end{array}$ \\
\hline 1 & $\begin{array}{l}\text { Agriculture, } \\
\text { Forestry and } \\
\text { Fisheries }\end{array}$ & 2.17 & $\begin{array}{l}59,129 \\
060.4\end{array}$ & 1.65 & $\begin{array}{l}44,442, \\
379.3\end{array}$ & 0.82 & $\begin{array}{l}- \\
401,794 \\
.1\end{array}$ & 1.54 & $\begin{array}{l}- \\
680,05 \\
2.2\end{array}$ & 0.35 & $\begin{array}{l}- \\
38,123 . \\
2\end{array}$ & 0.06 & $\begin{array}{l}- \\
162,99 \\
4.0\end{array}$ \\
\hline 2 & $\begin{array}{l}\text { Mining and } \\
\text { Excavation }\end{array}$ & 0.47 & $\begin{array}{l}8,409,6 \\
72.5\end{array}$ & 0.20 & $\begin{array}{l}3,181,4 \\
33.2\end{array}$ & 0.10 & $-5,749.7$ & 0.45 & $\begin{array}{l}168,65 \\
2.9\end{array}$ & 0.02 & $\begin{array}{l}- \\
1,092.7\end{array}$ & 0.05 & $\begin{array}{l}- \\
52,989 . \\
5\end{array}$ \\
\hline 3 & $\begin{array}{l}\text { Processing } \\
\text { industry }\end{array}$ & 0.35 & $\begin{array}{l}59,442, \\
009.8\end{array}$ & 0.85 & $\begin{array}{l}132,95 \\
0,224.3\end{array}$ & 1.10 & $\begin{array}{l}- \\
185,622 \\
.8\end{array}$ & 1.17 & $\begin{array}{l}76,994 . \\
1\end{array}$ & 0.84 & $\begin{array}{l}- \\
77,454 . \\
2\end{array}$ & 0.74 & $\begin{array}{l}- \\
84,939 . \\
4\end{array}$ \\
\hline 4 & $\begin{array}{l}\text { Electricity and } \\
\text { Gas supply }\end{array}$ & 0.92 & $\begin{array}{l}499,55 \\
5.6\end{array}$ & 1.00 & $\begin{array}{l}496,37 \\
2.2\end{array}$ & 1.13 & $-3,321.5$ & 1.93 & $\begin{array}{l}- \\
30.057\end{array}$ & 1.99 & $\begin{array}{l}- \\
2,122.4\end{array}$ & 1.14 & $3,099.9$ \\
\hline 5 & $\begin{array}{l}\text { Water Supply, } \\
\text { Waste } \\
\text { Management and } \\
\text { Recycling }\end{array}$ & 0.65 & $\begin{array}{l}170,58 \\
6.0\end{array}$ & 1.06 & $\begin{array}{l}255,44 \\
3.4\end{array}$ & 1.11 & $-2,048.5$ & 1.16 & $\overline{-}-\overline{1,555.9}$ & 1.15 & -964.7 & 1.25 & $\begin{array}{l}- \\
14,102 . \\
8\end{array}$ \\
\hline 6 & Construction & 0.53 & $\begin{array}{l}35,045, \\
699.2\end{array}$ & 0.81 & $\begin{array}{l}49,748, \\
807.9\end{array}$ & 1.31 & $\begin{array}{l}199,667 \\
.6\end{array}$ & 0.65 & $\begin{array}{l}85,999 . \\
1\end{array}$ & 1.34 & $9,971.7$ & 2.49 & $\begin{array}{l}854,25 \\
4.5\end{array}$ \\
\hline 7 & $\begin{array}{l}\text { Wholesale and } \\
\text { Retail Trade; Car } \\
\text { and Motorcycle } \\
\text { Repair }\end{array}$ & 1.48 & $\begin{array}{l}116,99 \\
1,979.0\end{array}$ & 1.17 & $\begin{array}{l}85,234 \\
303.0\end{array}$ & 0.80 & $\begin{array}{l}- \\
56,985 . \\
9\end{array}$ & 0.84 & $\begin{array}{l}- \\
53,676 . \\
5\end{array}$ & 0.98 & $\begin{array}{l}- \\
30,667 . \\
4\end{array}$ & 1.02 & $\begin{array}{l}- \\
28,188 . \\
1\end{array}$ \\
\hline 8 & $\begin{array}{l}\text { Transportation and } \\
\text { Storage }\end{array}$ & 1.57 & $\begin{array}{l}41,256, \\
200.6\end{array}$ & 0.91 & $\begin{array}{l}21,929 \\
685.9\end{array}$ & 0.67 & $\begin{array}{l}66,744 . \\
0\end{array}$ & 0.65 & $\begin{array}{l}43,360 \\
7\end{array}$ & 1.02 & $\begin{array}{l}22,767 . \\
0\end{array}$ & 1.08 & $\begin{array}{l}428,31 \\
4.3\end{array}$ \\
\hline
\end{tabular}




\begin{tabular}{|c|c|c|c|c|c|c|c|c|c|c|c|c|c|}
\hline \multirow{2}{*}{ \# } & \multirow{2}{*}{ Sectors } & \multicolumn{2}{|c|}{$\begin{array}{l}\text { Grobogan } \\
\text { Regency }\end{array}$} & \multicolumn{2}{|c|}{ Demak Regency } & \multicolumn{2}{|c|}{$\begin{array}{l}\text { Semarang } \\
\text { Regency }\end{array}$} & \multicolumn{2}{|c|}{$\begin{array}{c}\text { Kendal } \\
\text { Regency* }\end{array}$} & \multicolumn{2}{|c|}{ Salatiga City } & \multicolumn{2}{|c|}{ Semarang City } \\
\hline & & LQ & $\begin{array}{l}\text { Shift } \\
\text { share }\end{array}$ & LQ & $\begin{array}{l}\text { Shift } \\
\text { share }\end{array}$ & LQ & $\begin{array}{l}\text { Shift } \\
\text { share }\end{array}$ & LQ & $\begin{array}{l}\text { Shift } \\
\text { share }\end{array}$ & LQ & $\begin{array}{l}\text { Shift } \\
\text { share }\end{array}$ & LQ & $\begin{array}{l}\text { Shift } \\
\text { share }\end{array}$ \\
\hline 9 & $\begin{array}{l}\text { Provision of } \\
\text { Accommodation } \\
\text { and Food and } \\
\text { Drink }\end{array}$ & 1.42 & $\begin{array}{l}35,201 \\
106.0\end{array}$ & 0.78 & $\begin{array}{l}17,669, \\
699.0\end{array}$ & 0.97 & $\begin{array}{l}60,800 . \\
1\end{array}$ & 1.07 & $\begin{array}{l}111,34 \\
5.3\end{array}$ & 2.44 & $\begin{array}{l}56,601 . \\
3\end{array}$ & 1.02 & $\begin{array}{l}401,97 \\
7.8\end{array}$ \\
\hline 10 & $\begin{array}{l}\text { Information and } \\
\text { Communication }\end{array}$ & 0.71 & $\begin{array}{l}45,230, \\
586.2\end{array}$ & 0.56 & $\begin{array}{l}33,205 \\
208.7\end{array}$ & 0.98 & $\begin{array}{l}418,927 \\
.0\end{array}$ & 0.95 & $\begin{array}{l}283,95 \\
3.3\end{array}$ & 0.89 & $\begin{array}{l}47,228 . \\
5\end{array}$ & 2.16 & $\begin{array}{l}2,766,6 \\
98.3\end{array}$ \\
\hline 11 & $\begin{array}{l}\text { Financial Services } \\
\text { and Insurance }\end{array}$ & 1.46 & $\begin{array}{l}24,433, \\
435.9\end{array}$ & 0.87 & $\begin{array}{l}13,400, \\
500.8\end{array}$ & 1.28 & $\begin{array}{l}83,423 . \\
2\end{array}$ & 0.66 & $3,687.7$ & 1.31 & $\begin{array}{l}12,328 . \\
1\end{array}$ & 1.50 & $\begin{array}{l}204,66 \\
3.3\end{array}$ \\
\hline 12 & Real Estate & 1.26 & $\begin{array}{l}17,106, \\
411.8\end{array}$ & 0.73 & $\begin{array}{l}9,159,2 \\
77.7\end{array}$ & 1.76 & $\begin{array}{l}90,233 . \\
8\end{array}$ & 0.52 & $\begin{array}{l}50,813 . \\
9\end{array}$ & 2.84 & $\begin{array}{l}20,172 . \\
6\end{array}$ & 1.69 & $\begin{array}{l}514,33 \\
4.9\end{array}$ \\
\hline 13 & $\begin{array}{l}\text { Corporate } \\
\text { Services }\end{array}$ & 0.69 & $\begin{array}{l}2,687,6 \\
86.4\end{array}$ & 0.68 & $\begin{array}{l}2,428,9 \\
53.5\end{array}$ & 1.34 & $\begin{array}{l}31,581 . \\
8\end{array}$ & 0.76 & $\begin{array}{l}11,055 . \\
2\end{array}$ & 3.23 & $\begin{array}{l}18,628 . \\
7\end{array}$ & 1.71 & $\begin{array}{l}141,82 \\
1.2\end{array}$ \\
\hline 14 & $\begin{array}{l}\text { Government } \\
\text { Administration, } \\
\text { Defense and } \\
\text { Mandatory Social } \\
\text { Security }\end{array}$ & 1.25 & $\begin{array}{l}9,899,2 \\
83.8\end{array}$ & 1.28 & $\begin{array}{l}9,534,7 \\
45.3\end{array}$ & 1.02 & $\begin{array}{l}- \\
98,141 . \\
0\end{array}$ & 0.72 & $\begin{array}{l}- \\
62,774 . \\
9\end{array}$ & 1.95 & $\begin{array}{l}- \\
60,658 . \\
8\end{array}$ & 1.18 & $\begin{array}{l}- \\
152,05 \\
3.2\end{array}$ \\
\hline 15 & Education services & 1.18 & $\begin{array}{l}38,537 \\
900.9\end{array}$ & 1.08 & $\begin{array}{l}32,702, \\
155.8\end{array}$ & 0.92 & $\begin{array}{l}172,533 \\
.8\end{array}$ & 0.63 & $\begin{array}{l}88,001 . \\
4\end{array}$ & 1.18 & $\begin{array}{l}43,679 . \\
4\end{array}$ & 0.62 & $\begin{array}{l}403,40 \\
6.7\end{array}$ \\
\hline 16 & $\begin{array}{l}\text { Health and Social } \\
\text { Activities Services }\end{array}$ & 1.18 & $\begin{array}{l}10,326, \\
027.2\end{array}$ & 0.90 & $\begin{array}{l}7,324,9 \\
98.6\end{array}$ & 0.85 & $\begin{array}{l}37,608 . \\
9\end{array}$ & 0.78 & $\begin{array}{l}27,996 . \\
5\end{array}$ & 1.79 & $\begin{array}{l}22,358 . \\
1\end{array}$ & 0.85 & $\begin{array}{l}137,77 \\
1.0\end{array}$ \\
\hline 17 & Other Services & 1.78 & $\begin{array}{l}25,410, \\
957.3\end{array}$ & 1.63 & $\begin{array}{l}21,493, \\
662.8\end{array}$ & 0.82 & $\begin{array}{l}83,635 . \\
2\end{array}$ & 0.83 & $\begin{array}{l}37,404 . \\
8\end{array}$ & 0.65 & $9,249.9$ & 0.72 & $\begin{array}{l}177,75 \\
5.7\end{array}$ \\
\hline
\end{tabular}

Source: Author's Analysis, 2019

Based on the table of LQ and shift-share analysis results, it can be seen that Grobogan Regency has 10 base sectors, namely agriculture, trade, transportation, accommodation and food provision, financial services, real-estate, government administration, education services, health services, and others. Meanwhile, Grobogan Regency shows that the net-shift value of all sectors is positive, meaning that all sectors are competitive. Demak Regency has 7 basic sectors, namely agriculture, electricity supply, water supply, trade, government administration, education services, and other services; The shift-share analysis shows that Demak Regency has a net-shift value whereas all sectors are positive, meaning that they are all competitive. Semarang Regency, which has 8 basic sectors, including the processing industry, electricity supply, water supply, construction, financial services, real-estate, corporate services, and government administration. The shift-share analysis shows that Semarang Regency has 10 sectors with positive net-shift value, meaning that these 10 sectors are competitive. The Kendal Regency has 5 base sectors, including agriculture, processing industry, electricity supply, and accommodation, and food provision, while the shift-share analysis shows that Kendal Regency has 20 sectors with a positive net-shift value, meaning that these 20 sectors are competitive.

Meanwhile, Salatiga City, which has 11 base sectors, the shift-share analysis shows that the it has 10 sectors with a positive net-shift value, meaning that those 10 sectors are competititve. Semarang City has 11 basic sectors with shiftshare analysis indicating that it has 9 sectors with a positive net-shift value, which means that those 9 sectors are competitive. The leading, developing, underdeveloped, and potential sectors can be seen in Figure 1 as follow. 
SALATIGA CITY

Regional Share Growth Component (+)

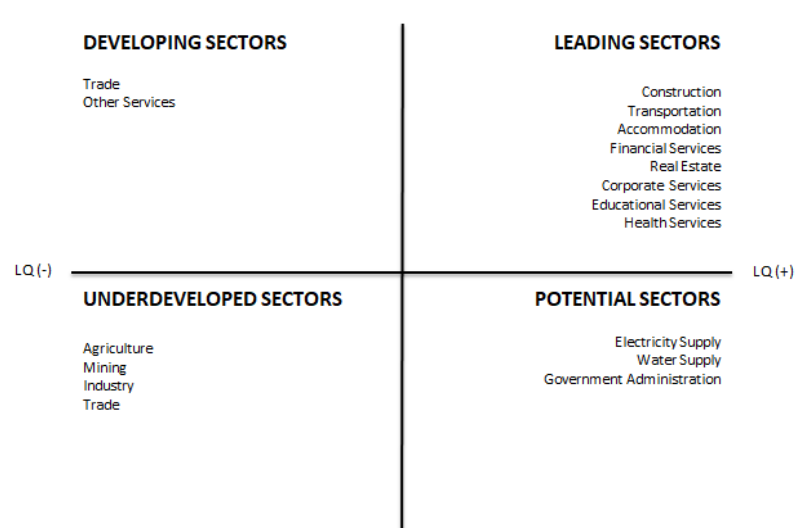

SEMARANG CITY
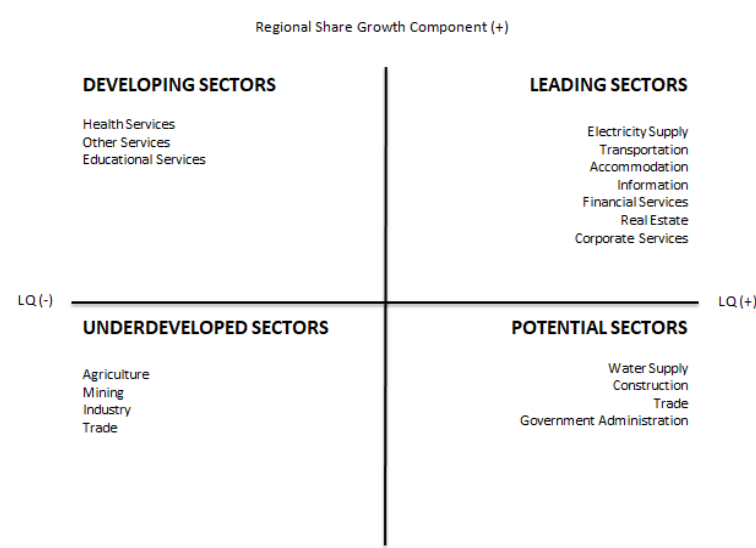

Regional Share Growth Component (-)

DEMAK REGENCY

Regional Share Growth Component (t)

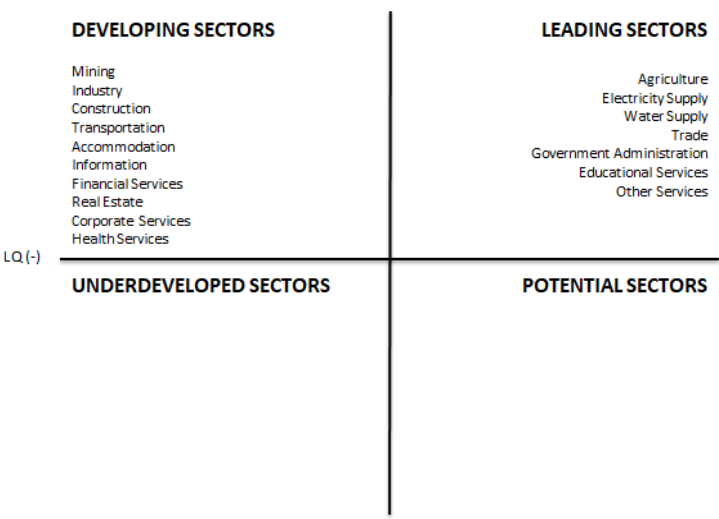

Regional Share Growth Component (-)
GROBOGAN REGENCY

Regional Share Growth Component (+)

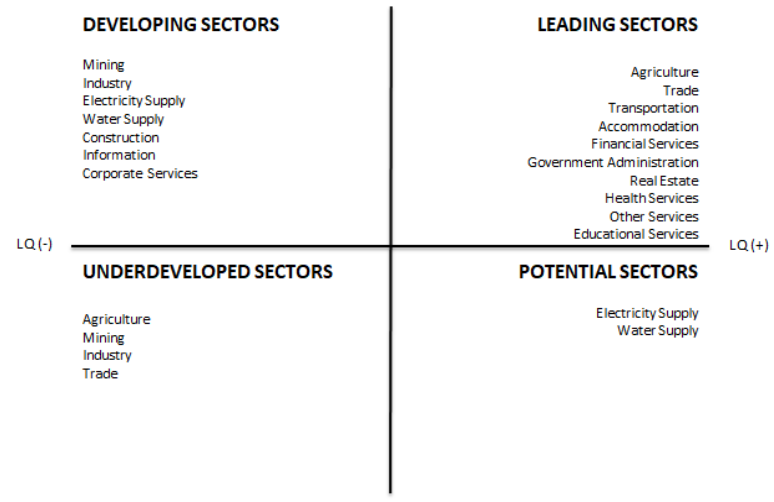

Regional Share Growth Component (-)

KENDAL REGENCY

Regional Share Growth Component (t)

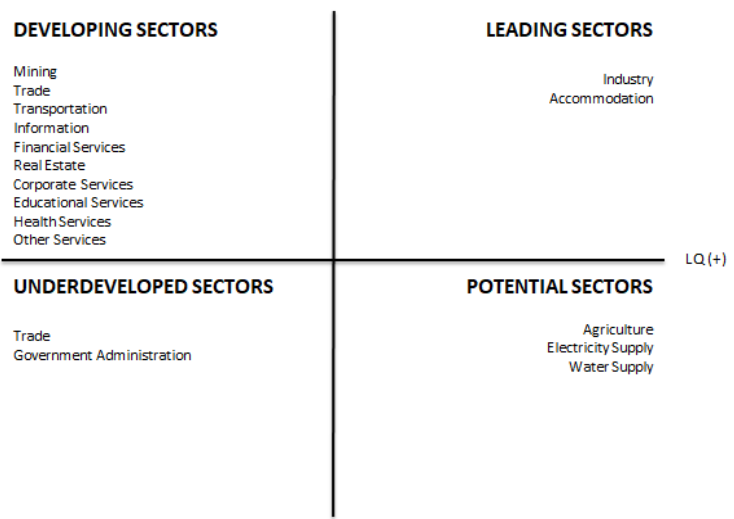

Regional Share Growth Component $(-)$

SEMARANG REGENCY
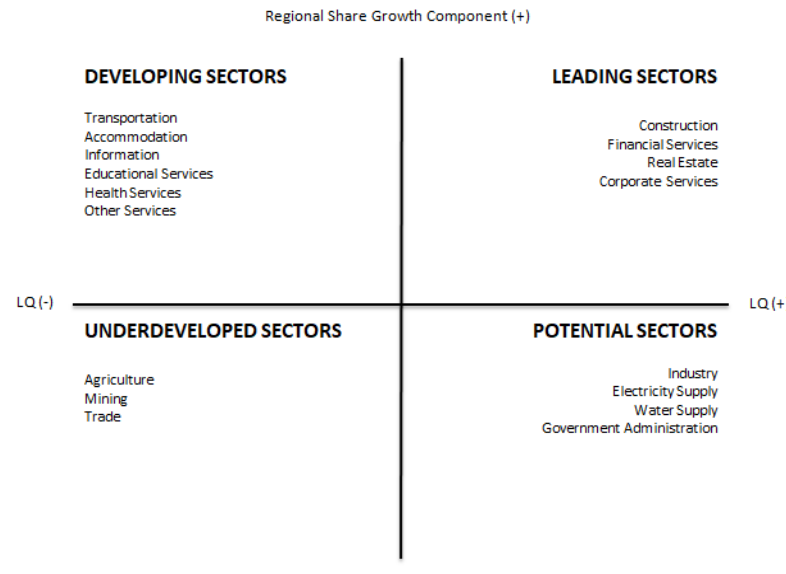

Regional Share Growth Component (-)

Figure 1 The Typology of Regency / City in Kedungsepur Area Based on Sector in GRDP 
Based on the typology of regencies / cities in the Kedungsepur Area based on sector in GDP, in relation to companies that are still operating as usual in several former residencies in Central Java divided by sectors, the data was summarized as follows:

Table 3 Companies that are still operating as usual by sector

\begin{tabular}{|l|c|}
\hline \multicolumn{1}{|c|}{ SECTOR } & Activity (\%) \\
\hline Electricity and Gas & 77.2 \\
\hline $\begin{array}{l}\text { Water and Waste } \\
\text { Management }\end{array}$ & 75.2 \\
\hline $\begin{array}{l}\text { Information and } \\
\text { Communication }\end{array}$ & 74.7 \\
\hline Farm and Nursery & 74.3 \\
\hline Health Services & 65.4 \\
\hline Financial Services & 64.8 \\
\hline $\begin{array}{l}\text { Trade and Vehicle } \\
\text { Reparation }\end{array}$ & 64.3 \\
\hline Mining and Excavation & 62.2 \\
\hline Real Estate & 61.8 \\
\hline Other Services & 50.5 \\
\hline Transportation and Storage & 49.4 \\
\hline Accommodation and Food & \\
\hline Processing Industry & 38.4 \\
\hline Corporate Services & \\
\hline Construction & \\
\hline Educational Services & \\
\hline Source: Central Statistics Burages & \\
\hline
\end{tabular}

Source: Central Statistics Bureau (BPS), 2020

The Kedungsepur Development Area is centered in the urban area of Semarang with development directions such as: 1. Integrating the development of the city of Semarang and its surrounding areas; 2 . Regional development based on leading sectors including: a) Trade and Services; b) Agriculture; c) Industry; d) Tourism; e) Fisheries; f) GeoThermal; g) Mining; and h) Oil and Natural Gas. Kedungsepur as a development area that plays an important role to support the economy of Central Java, should have a strategic role to be able to push back the rate of economic growth in this province.

\section{CONCLUSION}

Based on the results of the discussion above, it can be concluded that the leading sectors in each Kedungsepur development region must be optimized in order to support the economy in Central Java. Some of the leading MSME sectors can be provided with the most-needed assistance during the pandemic, including capital assistance, electricity bill, and tax relief. In addition to reducing disparities in economic growth among the regions in Kedungsepur, these leading sectors will be able to boost economic growth in Central Java during the pandemic by encouraging the growth of MSMEs in leading sectors in the Kedungsepur area.

\section{REFERENCES}

[1] Arsyad, Lincolin, Ekonomi Pembangunan, Edisi Kelima. Yogyakarta: BP STIE YKPN, 2016

[2] Blakely, Edward, Planning Local Economic Development Theory and Practice. New Delhi: Sage Publications, 2002

[3] Angka 2019

BPS. Kota Semarang Dalam

[4] BPS. Kabupaten Kendal

Dalam Angka. 2019

[5] Angka. 2019

BPS. Kota Salatiga Dalam

[6] BPS. Kabupaten Grobogan

Dalam Angka. 2019

[7] BPS. Kabupaten Semarang

Dalam Angka. 2019

[8] BPS. Kabupaten Demak

Dalam Angka. 2019

[9] BPS. Jawa Tengah Dalam

Angka. 2019

[10] BPS. Analisis hasil Survei Dampak Covid-19 Terhadap Pelaku Usaha Provinsi Jawa Tengah, 2020

[11] Darmawansyah, Pengembangan Komoditi Unggulan Sebagai Basis Ekonomi Daerah, Tesis, Program Pasca Sarjana IPB, Bogor, 2003

[12] Deky Aji Suseno. Pengambangan Daerah Berdasarkan Tipologi Pertumbuhan Ekonomi dan Ketimpangan Sektor di Wilayah Kedungsepur, Jurnal Ekonomi dan Kebijakan. Volume 8 No.1 (2015) 

jatengprov.go.id

[14] Hajeri, Erlinda Yurisinthae, Eva Dolorosa, Analisis Penentuan Sektor Unggulan Perekonomian di Kabupaten Kubu Raya. Jurnal Ekonomi, Bisnis, dan Kewirausahaan, Vol. 4, No. 2, 253-269, 2015.

[15] Hayter, Roger, The Dynamics of Industrial Location: The Factory, The Firm and The Production System. Chichester: John Wiley \& Son, 2000

[16] Hoover, Edgar M, An Introduction to Regional Economics. New York: Alfred A. Knopf, Inc, 1971.

[17] Khoir Akfini Didia, Analisis Ketimpangan Pembangunan di Kawasan Kedungsepur. Economics Deveopment Anaysis Journal 5 (1) (2016)

[18] Kuncoro, Mudrajad, Otonomi dan Pembangunan Daerah Reformasi, Perencanaan dan Peluang. Erlangga, 2004

[19] Laporan Perekonomian Provinsi Jawa Tengah.2020. Bank Indonesia.

[20] Mahmud Basuki, Febri Nugroho Mujiraharjo. Analisis Sektor Unggulan Kabupaten Sleman dengan Metode Shift Share dan Location Quotient. Jurnal Sains, Teknologi dan Industri, Vol. 15, No. 1, Desember, pp.52 - 60 ISSN 1693-2390 print / ISSN 2407-0939 online, 2017

[21] Peraturan Daerah Nomor 16 Tahun 2019 tentang Rencana Tata Ruang Wilayah Provinsi Jawa Tengah

[22] Robinson Tarigan, Ekonomi Regional: Teori dan Aplikasi, Bumi Aksara, Jakarta (ID), 2005

[23] Setyani Irmawati. Analisis Industri Unggulan di Provinsi Jawa Tengah. Jejak Vol 8 (2) (2015): 224-237, 2016

[24] Sukirno, Sadono, Teori Pengantar Makro Ekonomi. Jakarta: PT Raja Grafindo Persada, 2008

[25] Syafrizal, Pertumbuhan Ekonomi dan Ketimpangan Regional Wilayah Indonesia Bagian Barat. Prisma. LP3ES. Tahun XXVI hal. 27-38, 1997

[26] Todaro, M. P., Smith, S.C (2015), Economic Development, $12^{\text {th }}$ Edition, Pearson 